Acta Horticulturae et Regiotecturae 1

Nitra, Slovaca Universitas Agriculturae Nitriae, 2018, pp. 20-24

\title{
GLOBAL SOLAR RADIATION ANALYSIS OF THE MODIFIED SAVIN-ANGSTRÖM METHOD BY USING PYRANOMETERS CMP 6 AND CMP 11
}

\author{
Ján ČIMO*, Beáta NOVOTNÁ \\ Slovak University of Agriculture in Nitra, Slovak Republic
}

\begin{abstract}
Solar energy is one of the most available energy sources and the most ecological one. Currently, the firm Kipp \& Zonen belongs to prominent producer of sensors for measuring global radiation. These sensors are the most used ones in our country and also in network of meteorological measurements of WMO. Therefore, the two types of measuring sensors for global radiation (pyranometer PMP 11, CMP 6) in comparison with the calculation method Savin-Angström are analysed. By processing the experimental measurements of global radiation in locality Nitra, there can be observed differences between standard CMP 11 and CMP 6. The measured values by CMP 6 pyranometer in comparison with secondary standard CMP 11 are lower by about $21 \%$ to what corresponds to the accuracy level (First Class) of sensor CMP 6. Differences may have been caused by higher aberrance of non-linearity, aberrance at sunrise and sunset i.e. directional errors and also by the fact that sensor CMP 6 is not equipped with integrated temperature compensation. The similar situation was also in the comparison of global radiation, which was calculated according to the modified Savin-Angström method and CMP 11. Notional differences were 7\% compared with the measured values of CMP 11 standard.
\end{abstract}

Keywords: global radiation, pyranometer, Savin-Angström method

One of the most important agricultural requirements is information about condition and progress of atmospheric environment, which influences evolution of vegetation, diseases and pests and other prognosis (Meza, 1999). One of the most important and the most monitored component is global radiation, which is the main subject of our study at the meteorological station Nitra. Global radiation is sun radiation which incidents on the Earth's surface. As it is introduced in Kanuk (2007), solar radiation is the most important energy source, following the most processes in land to work. Radiation input power to biological systems determines a lot of processes in the system soil-planatmosphere (Czégény, 2016). Besides biological processes (photosynthesis, respiration, water and substances transport in plants, and others), evapotranspiration and through it also the total water balance are underlain through the energy balance (Čimo et al., 2014).

\section{Material and methods}

Systematic monitoring of atmosphere conditions started at the Slovak University of Agriculture in 1961. The original localization of its meteorological station did not fulfil the conditions for meteorological observation activity; therefore, the new automated meteorological station was initiated into operating in the Botanical Garden of the Slovak University of Agriculture in Nitra, in 2007. Later, in 2009, a specialized centre for measuring UVA, UVB and global radiation was added. Measurement and registration of global radiation is systematically done with using two separate datalogers situated at each station. Pyranometers from the leading producer Kipp \& Zonen are used. The automated meteorological station AWS 200 is equipped with the pyranometer CMP 6 and the specialized centre for global radiation is equipped with the pyranometer CMP 11 (Fig. 1).

CMP 6 has a similar detector to CMP 3, but it has improved performance due to the increased thermal mass and the double glass dome construction. It is recommended for costeffective, good quality measurements in meteorological and hydrological networks and agriculture. CMP 11 uses a different detector design with temperature compensation. It is a step up in performance from CMP 6, and particularly suitable for upgrading meteorological networks. The faster response time meets the requirements for solar energy research and development applications. CMP 11 is also ideal for use in sun tracker based solar monitoring stations.

For measurement evaluating accuracy of different pyranometers types in comparison with the used methodology of modified method for radiation calculation following the Savin-Angström, we were based on the Kipp \& Zonen data, so the pyranometer CMP 11 was determined as standard for the measurement accuracy. This pyranometer reaches aberration of less than $0.2 \%$ on 1,000 W.m ${ }^{-2}$ (Tab. 1). Several chosen months were analysed (March, April, May, June and July) in 2015 and 2016, and values of global radiation were monitored and recorded in 1 minute step. Consequently the recorded values for global radiation were compared with calculated values (from sunshine) 


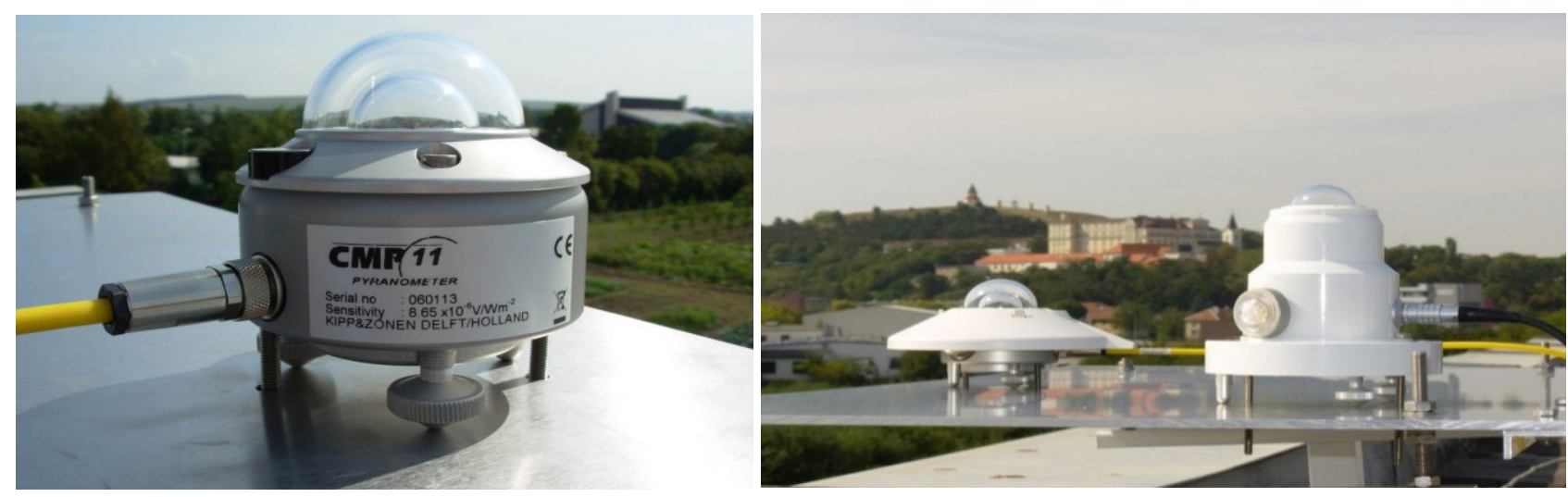

Fig. 1 Demonstration of pyranometers CMP 11 and CMP 6 at the meteorological station

according the mentioned Savin-Angström modified method for calculation of global radiation. Sunshine duration was observed with the heliograph Campbell-Stokes.

$$
G_{i}=G_{0 i}\left[1-l\left(1-\frac{s}{s_{0}}\right)\right], \quad \text { k.Wh.m }{ }^{-2}
$$

where:

$G_{i} \quad$ - global radiation in month, k.Wh.m ${ }^{-2}$

$G_{0 i} \quad$ - global radiation of clear sky in month, k.Wh.m ${ }^{-2}$

$k$ - coefficient of reflection and diffusion

$s \quad$ - sunshine, $\mathrm{h}$

$s_{0} \quad$ - astronomical sunshine, $\mathrm{h}$

Table 1 Kipp \& Zonen sensor specification

\begin{tabular}{|c|c|c|c|c|c|}
\hline Specification & CMP 3 & CMP 6 & CMP 11 & CMP 21 & CMP 22 \\
\hline ISO CLASSIFICATION & second Class & first Class & $\begin{array}{l}\text { secondary } \\
\text { standard }\end{array}$ & $\begin{array}{l}\text { secondary } \\
\text { standard }\end{array}$ & $\begin{array}{l}\text { secondary } \\
\text { standard }\end{array}$ \\
\hline Response time (95\%) & $<18 \mathrm{~s}$ & $<18 \mathrm{~s}$ & $<5 s$ & $<5 s$ & $<5 s$ \\
\hline $\begin{array}{l}\text { Zero offsets } \\
\text { Thermal radiation } \\
\text { Temperature change }\end{array}$ & $\begin{array}{l}<15 \mathrm{~W} \cdot \mathrm{m}^{-2} \\
<5 \mathrm{~W} \cdot \mathrm{m}^{-2}\end{array}$ & $\begin{array}{l}<\mathrm{W} \cdot \mathrm{m}^{-2} \\
<4 \mathrm{~W} \cdot \mathrm{m}^{-2}\end{array}$ & $\begin{array}{l}<7 \mathrm{~W} \cdot \mathrm{m}^{-2} \\
<2 \mathrm{~W} \cdot \mathrm{m}^{-2}\end{array}$ & $\begin{array}{l}<\mathrm{W} \cdot \mathrm{m}^{-2} \\
<2 \mathrm{~W} \cdot \mathrm{m}^{-2}\end{array}$ & $\begin{array}{l}<\mathrm{W} \cdot \mathrm{m}^{-2} \\
<1 \mathrm{~W} \cdot \mathrm{m}^{-2}\end{array}$ \\
\hline Non-stability (change/year) & $<1 \%$ & $<1 \%$ & $<0.5 \%$ & $<0.5 \%$ & $<0.5 \%$ \\
\hline Non-linearity (0 to $1,000 \mathrm{~W} \cdot \mathrm{m}^{-2}$ ) & $<1 \%$ & $<1 \%$ & $<0.2 \%$ & $<0.2 \%$ & $<0.2 \%$ \\
\hline $\begin{array}{l}\text { Directional error } \\
\text { (up to } 80^{\circ} \text { with } \\
1,000 \mathrm{~W} \cdot \mathrm{m}^{-2} \text { beam) }\end{array}$ & $<20$ W.m $\mathrm{m}^{-2}$ & $<20$ W.m $\mathrm{m}^{-2}$ & $<10$ W.m $\mathrm{m}^{-2}$ & $<10$ W.m $\mathrm{m}^{-2}$ & $<5 \mathrm{~W} \cdot \mathrm{m}^{-2}$ \\
\hline $\begin{array}{l}\text { Temperature dependence } \\
\text { of sensitivity }\end{array}$ & $\begin{array}{c}<5 \% \\
\left(-10{ }^{\circ} \mathrm{C} \text { to }+40{ }^{\circ} \mathrm{C}\right)\end{array}$ & $\begin{array}{c}<4 \% \\
\left(-10^{\circ} \mathrm{C} \text { to }+40^{\circ} \mathrm{C}\right)\end{array}$ & $\begin{array}{c}<1 \% \\
\left(-10^{\circ} \mathrm{C} \text { to }+40^{\circ} \mathrm{C}\right)\end{array}$ & $\begin{array}{c}<1 \% \\
\left(-20^{\circ} \mathrm{C} \text { to }+50^{\circ} \mathrm{C}\right)\end{array}$ & $\begin{array}{c}<0.5 \% \\
\left(-20{ }^{\circ} \mathrm{C} \text { to }+50{ }^{\circ} \mathrm{C}\right)\end{array}$ \\
\hline Tilt error (at 1,000 W.m ${ }^{-2}$ ) & $<1 \%$ & $<1 \%$ & $<0.2 \%$ & $<0 ., 2 \%$ & $<0.2 \%$ \\
\hline \multicolumn{6}{|l|}{ Other specifications } \\
\hline Sensitivity & 5 to $20 \mu \mathrm{V} / \mathrm{W} / \mathrm{m}^{2}$ & 5 to $20 \mu \mathrm{V} / \mathrm{W} / \mathrm{m}^{2}$ & 7 to $14 \mu \mathrm{V} / \mathrm{W} / \mathrm{m}^{2}$ & 7 to $14 \mu \mathrm{V} / \mathrm{W} / \mathrm{m}^{2}$ & 7 to $14 \mu \mathrm{V} / \mathrm{W} / \mathrm{m}^{2}$ \\
\hline Impedance & 20 to $200 \Omega$ & 20 to $200 \Omega$ & 10 to $100 \Omega$ & 10 to $100 \Omega$ & 10 to $100 \Omega$ \\
\hline Level accuracy & $1^{\circ}$ & $0.1^{\circ}$ & $0.1^{\circ}$ & $0.1^{\circ}$ & $0.1^{\circ}$ \\
\hline Operating temperature & $-40^{\circ} \mathrm{C}$ to $+80^{\circ} \mathrm{C}$ & $-40^{\circ} \mathrm{C}$ to $+80^{\circ} \mathrm{C}$ & $-40^{\circ} \mathrm{C}$ to $+80^{\circ} \mathrm{C}$ & $-40^{\circ} \mathrm{C}$ to $+80^{\circ} \mathrm{C}$ & $-40^{\circ} \mathrm{C}$ to $+80^{\circ} \mathrm{C}$ \\
\hline Spectral range ( $50 \%$ points) & 300 to $2,800 \mathrm{~nm}$ & 285 to $2,800 \mathrm{~nm}$ & 285 to $2,800 \mathrm{~nm}$ & 285 to $2,800 \mathrm{~nm}$ & 200 to $3,600 \mathrm{~nm}$ \\
\hline $\begin{array}{l}\text { Typical signal output for } \\
\text { atmospheric applications }\end{array}$ & 0 to $20 \mathrm{mV}$ & 0 to $20 \mathrm{mV}$ & 0 to $15 \mathrm{mV}$ & 0 to $15 \mathrm{mV}$ & 0 to $15 \mathrm{mV}$ \\
\hline Maximum irradiance & $2,000 \mathrm{~W} \cdot \mathrm{m}^{-2}$ & $2,000 \mathrm{~W} \cdot \mathrm{m}^{-2}$ & 4,000 W. $\mathrm{m}^{-2}$ & 4,000 W.m. ${ }^{-2}$ & 4,000 W.m. ${ }^{-2}$ \\
\hline Expected daily uncertainty & $<10 \%$ & $<10 \%$ & $<10 \%$ & $<10 \%$ & $<10 \%$ \\
\hline Recommended applications & $\begin{array}{l}\text { economical } \\
\text { solution } \\
\text { for routine } \\
\text { measurements in } \\
\text { weather stations, } \\
\text { field testing }\end{array}$ & $\begin{array}{l}\text { good quality } \\
\text { measurements } \\
\text { for hydrology } \\
\text { networks, } \\
\text { greenhouse } \\
\text { climate control }\end{array}$ & $\begin{array}{l}\text { meteorological } \\
\text { networks, PV } \\
\text { panel and } \\
\text { thermal collector } \\
\text { testing, material } \\
\text { testing }\end{array}$ & $\begin{array}{l}\text { meteorological } \\
\text { networks, } \\
\text { reference } \\
\text { measurements in } \\
\text { extreme climates, } \\
\text { polar or arid }\end{array}$ & $\begin{array}{l}\text { scientific research } \\
\text { requiring the } \\
\text { highest level of } \\
\text { measurement } \\
\text { accuracy and } \\
\text { reliability }\end{array}$ \\
\hline
\end{tabular}



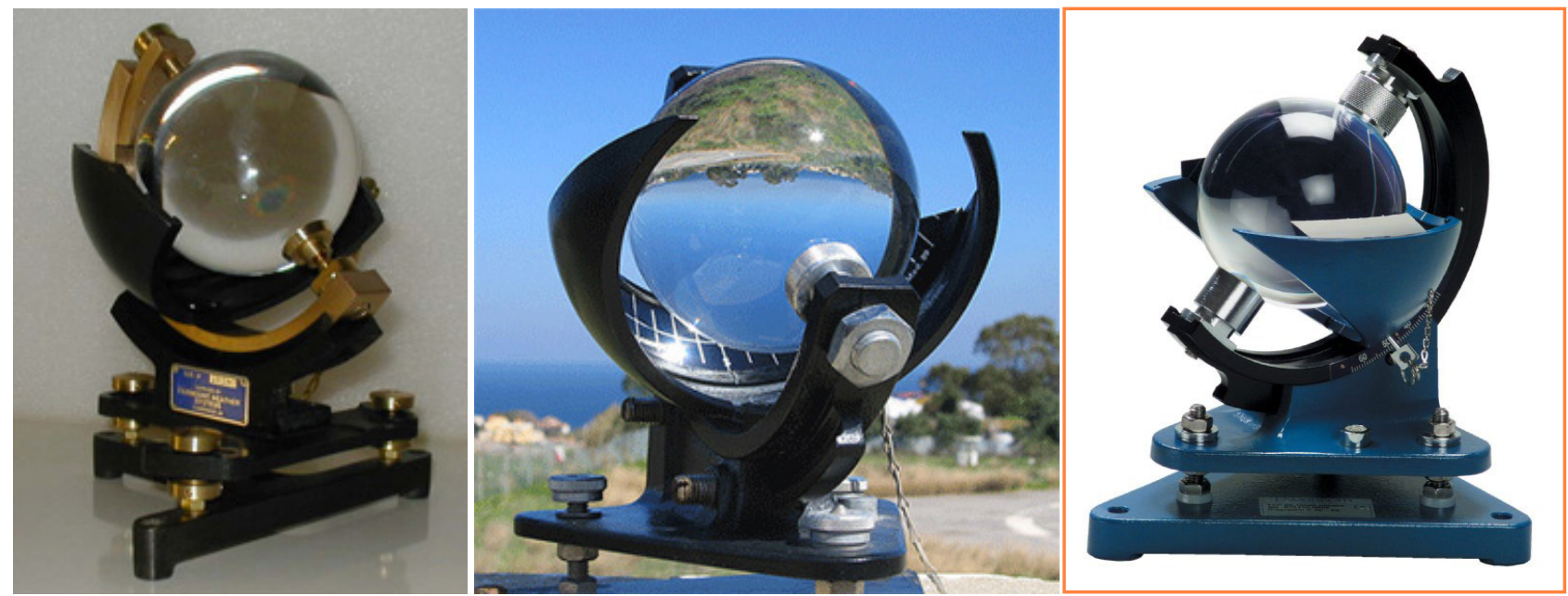

Fig. 2 Demonstration of Campbell-Stokes for measurement of sunshine

\section{Results and discussion}

Experimental measurements processing global radiation in Nitra produced several results. Values of global radiation according to the modified Savin-Angström methodology and by direct measurement using the CMP 6 and CMP 11 are listed in Figures 3-12.

From calculated and measured values there may be seen differences between the CMP 11 standards and the data measured by the pyranometer CMP 6 and the calculated values of global radiation. We observed that the values measured with the CMP 6 in comparison with the secondary standard CMP 11 (Table 2 and 3) are lower by about $21 \%$ to what corresponds with the level of accuracy established by producer (first class) of the sensor CMP 6.

Differences of the measured values between each sensors may be caused by greater non-linearity mistake of sensor $\left(1 \%-\left(0\right.\right.$ to $\left.\left.1,000 \mathrm{~W} \cdot \mathrm{m}^{-2}\right)\right)$, or a mistake caused by sunrise and sunset i.e. directional error (up to $80^{\circ}$ with 1,000 W. $\mathrm{m}^{-2}$ beam), but also because the sensor CMP 6 is not equipped with the integrated temperature compensation and, therefore, it has higher temperature dependency.

Comparison of global radiation calculated according to the modified Savin-Angström method and the CMP 11 sensor is similar. The presented difference was $7 \%$ in
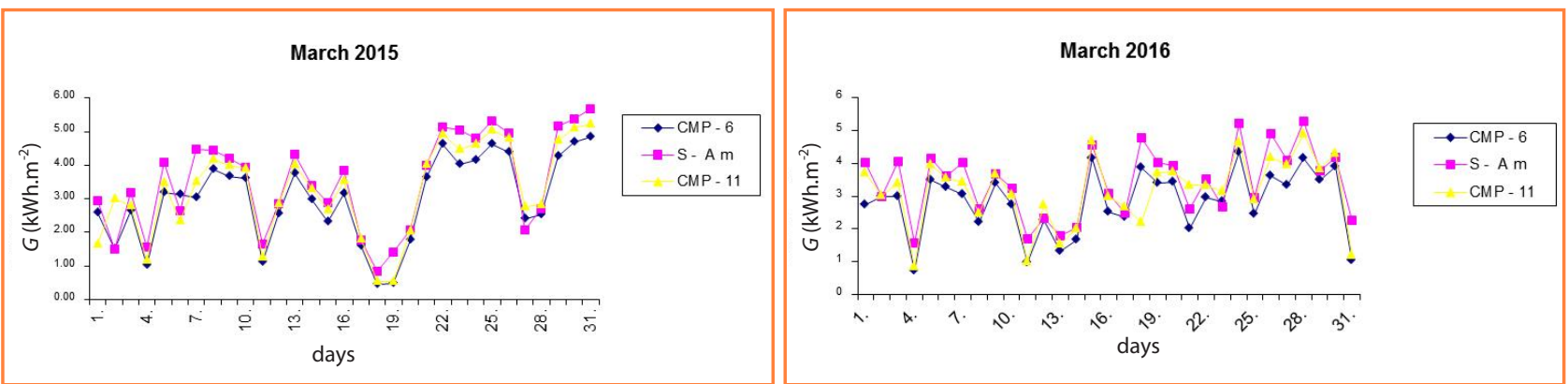

Fig. 3-4 Comparison of global radiation course measured with the CMP 6, CMP 11 and the Savin-Angström calculation method (March; 2015, 2016)
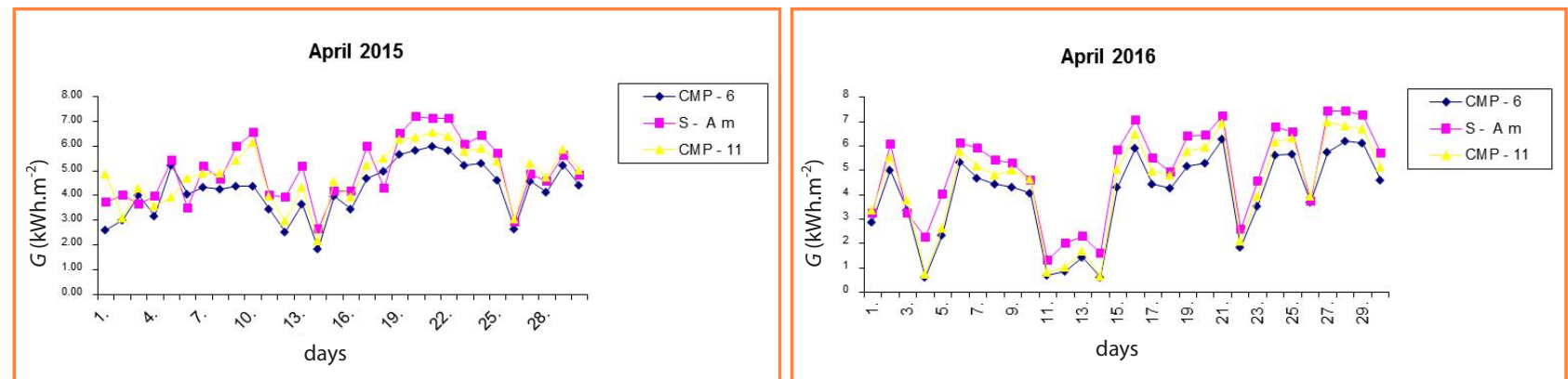

Fig. 5-6 Comparison of global radiation course measured with the CMP 6, CMP 11 and the Savin-Angström calculation method (April; 2015, 2016) 

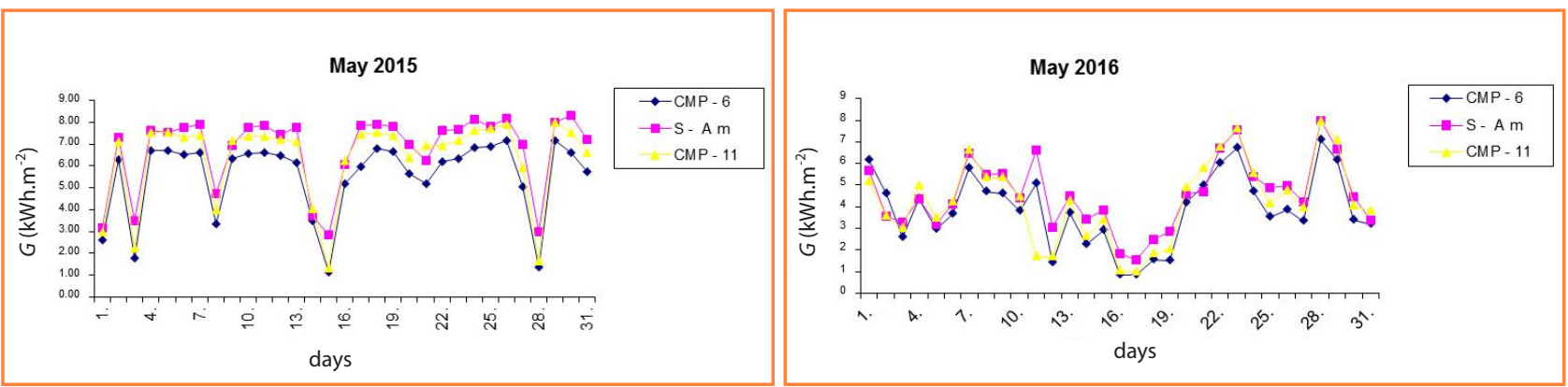

Fig. 7-8 Comparison of global radiation course measured with CMP 6, CMP 11 and Savin-Angström calculation method (May; 2015, 2016)
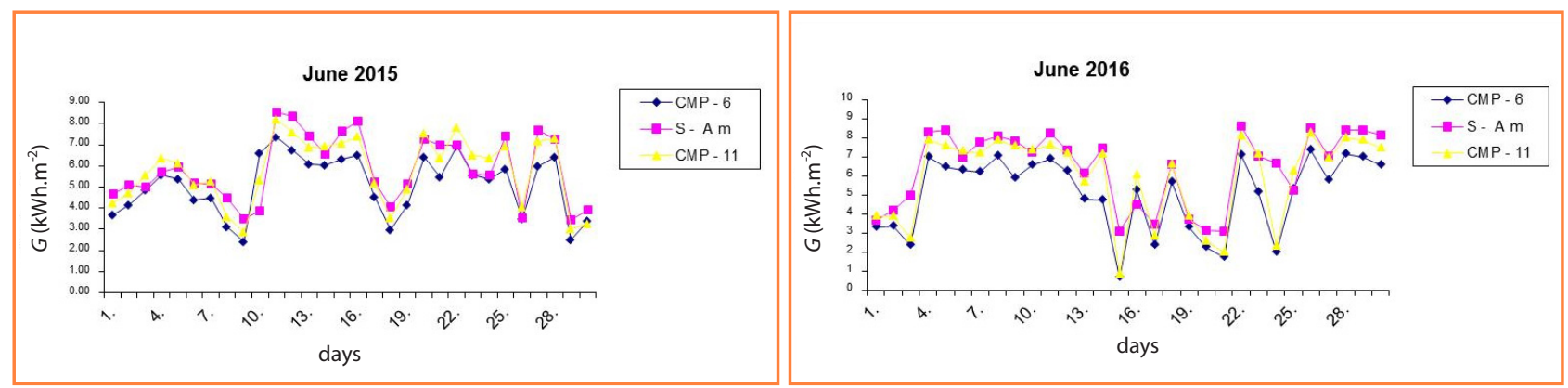

Fig. 9-10 Comparison of global radiation course measured with CMP 6, CMP 11 and Savin-Angström calculation method (June; 2015, 2016)
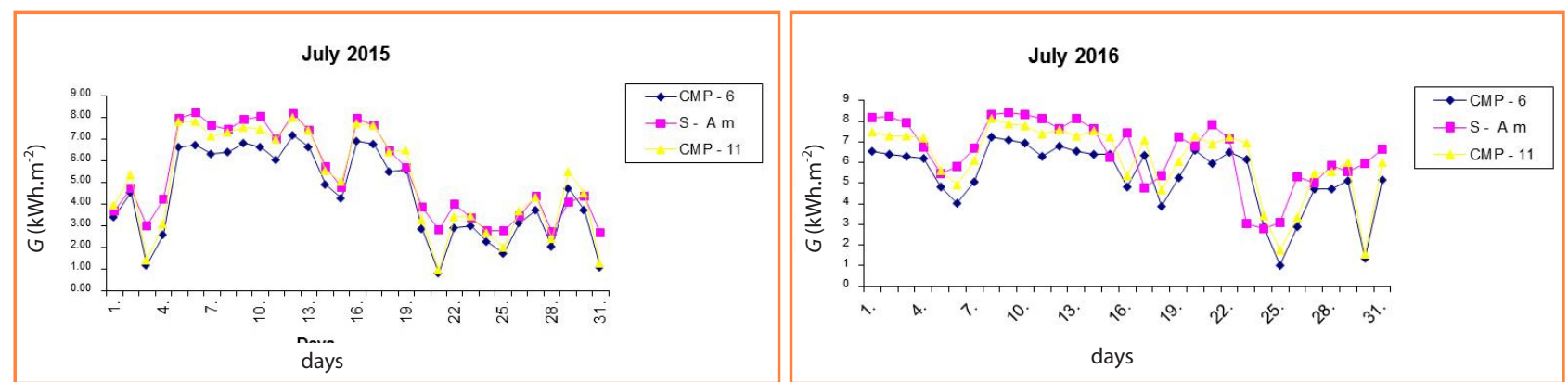

Fig. 11-12 Comparison of global radiation course measured with the CMP 6, CMP 11 and the Savin-Angström calculation method (July; 2015, 2016)

Table 2 Percentage difference of global radiation values measured by the CMP 6 sensor and the Savin-Angström method compared with the CMP 11 sensor values (2015)

\begin{tabular}{|l||c|c|c|c|c|c|c|}
\hline \multirow{2}{*}{ Sensor } & \multicolumn{7}{c|}{ Year 2015 } \\
\cline { 2 - 8 } & III. & IV. & V. & VI. & VII. & X. & sum \\
\hline CMP 11 vs. CMP 6 (\%) & 16.4 & 19.6 & 21.5 & 17.1 & 19.5 & 20.7 & 19.1 \\
\hline CMP 11 vs. S-A (\%) & 7.1 & 5.6 & 6.4 & 2.1 & 4.2 & 12.3 & 6.3 \\
\hline
\end{tabular}

Table 3 Percentage difference of global radiation values measured by the CMP 6 sensor and the Savin-Angström method compared with the CMP 11 sensor values (2016)

\begin{tabular}{|l||c|c|c|c|c|c|c|}
\hline \multirow{2}{*}{ Sensor } & \multicolumn{7}{c|}{ Year 2016 } \\
\cline { 2 - 9 } & III. & IV. & V. & VI. & VII. & X. & sum \\
\hline \hline CMP 11 vs. CMP 6 (\%) & 20.1 & 24.5 & 18.2 & 23.6 & 25.1 & 15.8 & 22.2 \\
\hline CMP 11 vs. S-A (\%) & 7.1 & 11.2 & 4.8 & 5.3 & 8.7 & 8.6 & 7.6 \\
\hline
\end{tabular}


adversum to the measured values of CMP 11 standard (Table 2 and 3). These differences may be caused by input data on sunshine. Entering value on sunshine (in hours) using the Savin-Angström methodology does not take into account the intensity of global radiation in different time period during the day.

\section{Conclusion}

To sum up, it is possible to say that in comparison with the pyranometer CMP 11, which is used within the World Meteorological Organization, the mentioned calculation method of Savin-Angström seems to be more accurate for the determination of global radiation for our geographical latitude than the measurements made using the pyranometer CMP 6.

\section{References}

ČIMO, J. et al. 2014. Biometeorológia. Nitra : SPU, 2014, 145 p. ISBN 978-80-552-1219-7.

ČIMO, J. et al. 2012. Praktická biometeorológia 1. Nitra : SPU, 2012, 201 p. ISBN 978-80-552-0771-1.
CZÉGÉNY, G. et al. 2016. UV-B effects on leaves - Oxidative stress and acclimation in controlled environments. In Plant Science, vol. 248, 2016, July, pp. 57-63.

KANUK, J. 2007. Analýza solárneho žiarenia pre urbánne územia. In Zborník zo VIII. vedeckej konferencie doktorandov a mladých vedeckých pracovníkov, Nitra: UKF, 2007. ISBN 978-80-8094-106-2. MEZA, F. - VARAS, E. 1999. Estimation of mean monthly solar global radiation as a function of temperature. In Agricultural and Forest Meteorolog, Elsevier, 1999, pp. 231-241. Dostupné na: <https://pdfs.semanticscholar. org/9572/744d791c1f4966c4ffdea920eaecd2e6e7b4.pdf>

ŠPÁNIK, F. et. al. 2009. Agroklimatické hodnotenie krajiny a základy agroklimatickej rajonizácie. Nitra : SPU, 2009, 88 p. ISBN 978-80-552-0236-5.

ŠPÁNIK, F. - TOMLAIN, J. 1983. Časové rozloženie slnečnej energie a možnosti jej využívania v polnohospodárskych oblastiach ČSSR. Nitra - Bratislava : OVHZM ČSAZ, 1983.

SUNITA, K. et al. Impact of increasing Ultraviolet-B (UV-B) radiation on photosynthetic processes. In Journal of Photochemistry and Photobiology B: Biology, vol. 137, 2014, August, pp. 55-66. 